\title{
Impaired Verbal Communication: diagnosis review in patients with Amyotrophic Lateral Sclerosis
}

\author{
Comunicação verbal prejudicada: revisão do diagnóstico em pacientes com Esclerose Lateral Amiotrófica
}

Comunicación Verbal Prejudicada: revisión del diagnóstico en pacientes con Esclerosis Lateral Amiotrófica

\section{Amanda Holanda Severo', Zuila Maria de Figueiredo Carvalho', Marcos Venícios de Oliveira Lopes', Renata Sá Ferreira Brasileiro', Deyse Cardoso de Oliveira Braga'}

' Universidade Federal do Ceará. Fortaleza, Ceará, Brazil.

\author{
How to cite this article: \\ Severo AH, Carvalho ZMF, Lopes MVO, Brasileiro RSF, Braga DCO. Impaired Verbal \\ Communication diagnosis review in patients with Amyotrophic Lateral Sclerosis. \\ Rev Bras Enferm [Internet]. 2018;71(6):3063-73. DOI: http://dx.doi.org/10.1590/0034-7167-2017-0763
}

Submission: 10-31-2017 Approval: 04-26-2018

\begin{abstract}
Objective: To review the contents of the nursing diagnosis of Impaired Verbal Communication in patients with Amyotrophic Lateral Sclerosis. Method: For the review of this diagnosis we used the integrative review. The 21 selected articles were submitted to a careful concept analysis for the definition of the diagnostic concept and review of its elements. Results: It is recommended, in addition to a new definition for the diagnosis of Impaired Verbal Communication, the incorporation of twelve Risk Factors, the maintenance of three others and the relocation of a Defining Characteristic for Risk Factor. It is also recommended the incorporation of nine Defining Characteristics and the modification of the nomenclature of the other three that already make up the NANDA-I. Conclusion: The content review process subsidized a clarification of the chosen concept, contributing to a future refinement and improvement of the study diagnosis and its components present in NANDA-I.
\end{abstract}

Descriptors: Nursing Diagnosis; Review; Validation Studies; Amyotrophic Lateral Sclerosis; Communication Disorders.

\section{RESUMO}

Objetivo: Revisar o conteúdo do diagnóstico de enfermagem de Comunicação Verbal Prejudicada em pacientes com Esclerose Lateral Amiotrófica. Método: Para a revisão do referido diagnóstico, utilizou-se a revisão integrativa. Os 21 artigos selecionados foram submetidos a uma análise de conceito criteriosa para a definição do conceito diagnóstico e revisão de seus elementos. Resultados: Recomenda-se, além de uma nova definição para o diagnóstico de Comunicação Verbal Prejudicada, a incorporação de doze Fatores Relacionados, a manutenção de outros três e a realocação de uma Característica Definidora para Fator Relacionado. Recomendase também a incorporação de nove Características Definidoras e a modificação da nomenclatura de outras três que já compõem a NANDA-I. Conclusão: $O$ processo de revisão de conteúdo subsidiou uma clarificação do conceito escolhido, contribuindo para um futuro refinamento e aprimoramento do diagnóstico em estudo e de seus componentes presentes na NANDA-I.

Descritores: Diagnóstico de Enfermagem; Revisão; Estudos de Validação; Esclerose Amiotrófica Lateral; Transtornos da Comunicação.

\section{RESUMEN}

Objetivo: Revisar el contenido del diagnóstico de enfermería de Comunicación Verbal Prejudicada en pacientes con Esclerosis Lateral Amiotrófica. Método: Para la revisión de dicho diagnóstico, se utilizó la revisión integrativa. Los 21 artículos seleccionados fueron sometidos a un análisis de concepto criterio para la definición del concepto diagnóstico y revisión de sus elementos. Resultados: Se recomienda, además de una nueva definición para el diagnóstico de Comunicación Verbal Prejudicada, la incorporación de doce Factores Relacionados, el mantenimiento de otros tres y la reubicación de una Característica Definidora para Factor Relacionado. Se recomienda también la incorporación de nueve Características Definidoras y la modificación de la nomenclatura de otras tres que ya componen la NANDA-I. Conclusión: El proceso de revisión de contenido subsidió una clarificación del concepto escogido, contribuyendo para un futuro refinamiento y perfeccionamiento del diagnóstico en estudio y de sus componentes presentes en la NANDA-I.

Descriptores: Diagnóstico de Enfermería; Revisión; Estudios de Validación; Esclerosis Amiotrófica Lateral; Trastornos de la Comunicación. 


\section{INTRODUCTION}

NANDA-I defines the nursing diagnosis as "clinical judgment about a human response to health conditions/life processes, or a vulnerability to that response, by an individual, family, group or community"(1). Therefore, the importance of the study of nursing diagnoses for the construction of an accurate clinical reasoning about the health conditions of a specific population.

The identification of nursing diagnoses, in the professional practice of nurses, is essential for the planning of their actions in order to provide quality and harmless care, respecting the needs of the patient. Once the main needs presented by the patients are known, it is possible to establish the nursing diagnoses and propose interventions that provide improvement in the health/illness condition of the client.

In this sense, the review and validation of nursing diagnoses are necessary for the development of clinical practice and should be one of the objectives of Nursing, so that the care process is performed safely ${ }^{(2)}$.

In the present study, we opted to analyze the nursing diagnosis of Impaired Verbal Communication in patients with Amyotrophic Lateral Sclerosis (ALS). The delimitation of the aforementioned diagnosis in ALS patients is supported by the existing literature gap in diagnostic studies for this public and the need to refine NANDA-I diagnoses in specific problems ${ }^{(2)}$.

The refinement of the nursing diagnosis of Impaired Verbal Communication will contribute to a better definition of the Risk Factors and specific defining characteristics ${ }^{2}$ for patients with ALS. Thus, nursing care can be directed to a specific diagnosis often found in patients with ALS, aiming to promote the health of these individuals.

The performance of this research was based on the following questions: Does the definition of Impaired Verbal Communication diagnosis in NANDA-I provide clear and representative description? What is the concept of Impaired Verbal Communication in ALS? What are the defining characteristics and risk factors of the nursing diagnosis of Impaired Verbal Communication in people with ALS? Are there other defining characteristics and risk factors of this diagnosis, not included in the taxonomy of NANDA-I, that are manifested in people with ALS? Are further appointments required for the defining characteristics and risk factors that already make up the diagnosis of Impaired Verbal Communication in NANDA-I in ALS subjects?

\section{OBJECTIVE}

To review the contents of the nursing diagnosis of Impaired Verbal Communication in patients with Amyotrophic Lateral Sclerosis.

\section{METHOD}

This study is a review of the content of the diagnosis of Impaired Verbal Communication, developed from a concept analysis, using integrative review as a method. In order to reach the proposed goal, we chose to follow the model of Lopes, Silva and $\mathrm{Araujo}^{(3)}$, which presents three stages: concept analysis, content analysis by specialists and analysis of the accuracy of clinical indicators. However, the study in question only addressed the first stage, being the second and third for later studies due to the impossibility of performing all the steps, at the moment.

In order to conduct the concept analysis, the method proposed by Walker and Avant ${ }^{(4)}$, and the steps of the integrative review of the literature proposed by Whittemore and Knafl(5) were selected because they could contribute substantially to the execution this step. Although they occur concomitantly, they are described separately.

Literature Integrative Review Method by Whittemore and Knafl

The steps for the operationalization of the integrative review of Whittemore and Knafl(5) are: 1. Identification of the research question; 2. Search in literature; 3 . Evaluation of data; 4. Data analysis; and 5 . Presentation of results.

To achieve the first stage, the topic Impaired Verbal Communication was selected: determinants and consequent in individuals with $A L S$. In order to direct the integrative review, the following questions were formulated: How is Impaired Verbal Communication presented for ALS patients in the literature? What are the elements of this nursing diagnosis in individuals with ALS?

The second step occurred through online access to the databases: National Library of Medicine and National Institutes of Health (PubMed), Scopus, Cochrane, Science direct, Latin American \& Caribbean Literature in Health Sciences (LILACS) and Cumulative Index to Nursing and Allied Health Literature (CINAHL). We used the controlled descriptors "Amyotrophic Lateral Sclerosis" AND "Communication Disorders" and their respective equivalent terms, in the English and Spanish languages, extracted from the DeCs (Descriptors in Health Sciences) of the Virtual Health Library Portal (VHL) and MeSH Subject Headings) of the National Library, respecting the terminology used in each selected database.

The following inclusion criteria were established for the selection of articles: published in Portuguese, English or Spanish; the study objective; approach analyzed; answer the guiding questions; complete and electronically available. As exclusion criteria: studies in editorial format and letters to the editor. It should be emphasized that, since it was not possible to search for articles in its entirety, directly in the selected databases, the portal of the Coordination of Improvement of Higher Education Personnel (CAPES - Coordenação de Aperfeiçoamento de Pessoal de Nível Superior) was considered as a data source, as well as the electronic address www.google.com. The bibliographic search occurred in August 2015.

The research was carried out at each base in a single day, with a recording of the pages found, while the selection of the publications was carried out in the following days. For the selection of the studies, the title and summary were initially read for prior assessment and certification that it had elements that would serve as a basis for the intended conceptual analysis. In case of doubts, whether or not the article met the inclusion and exclusion criteria, it was decided to include it for a later reading of the full article.

Then, the selected articles were subjected to careful and thorough reading for content analysis and to certify that they contained basic elements for the intended conceptual approach. 
A third reading was carried out, highlighting fundamental elements to the conceptual analysis. The selection process of the articles was carried out from August to October 2015 and is presented in the following figure.

After the bibliographic search procedure, 21 publications were selected, making up the final sample of included studies to support the analysis of the concept "Communication Disorders" in individuals with ALS, presented in Figure 2.

The third step consisted of data evaluation, conducted in November 2015, and weighed the strength of evidence from the studies. For the classification of the level of evidence of the studies, the classification proposed by Melnyk and Fineout-Overholt ${ }^{(6)}$.
The fourth step concerns the data analysis, thus the information extracted from the studies was identified and documented in a concise manner. In addition, as part of Walker and Avant's concept analysis, during each reading of the selected studies, screenings were performed that identified the critical, antecedent and consequent attributes of the nursing diagnosis of Impaired Verbal Communication. This stage was carried out from November 2015 to April 2016.

The fifth and last stage of the integrative review, carried out from May to July 2016, concerns the presentation of the review/ synthesis of knowledge and will be discussed according to the relevant literature.

\section{PUBMED: 277 articles found \\ $1^{\text {st }}$ reading: titles and abstracts of articles \\ - 165 did not approach the thematic \\ - 39 were not available electronically \\ - 49 were in languages other than English, Portuguese and Spanish \\ SUBTOTAL OF STUDIES INCLUDED: 24 \\ $2^{\text {nd }}$ and $3^{\text {rd }}$ reading: full-text articles \\ - 8 do not respond to research questions \\ - 2 cartas ao editor \\ TOTAL OF STUDIES INCLUDED: 14}

\section{COCHRANE: 38 articles found}

$1^{\text {st }}$ reading: titles and abstracts of articles

- 36 did not approach the thematic

- 1 were not available electronically

SUBTOTAL OF STUDIES INCLUDED: 1

$2^{\text {nd }}$ and $3^{\text {rd }}$ reading: full-text articles

- 1 does not respond to research questions

TOTAL OF STUDIES INCLUDED: 0

\begin{tabular}{|l|}
\hline SCOPUS: 134 articles found \\
\hline $\mathbf{1}^{\text {st }}$ reading: titles and abstracts of articles \\
- 91 did not approach the thematic \\
- 15 were not available electronically \\
Portuguese and Spanish \\
SUBTOTAL OF STUDIES INCLUDED: 16 \\
\hline $\mathbf{2}^{\text {nd }}$ and $3^{\text {rd }}$ reading: full-text articles \\
- 9 do not respond to research questions \\
- 5 were repeated in other databases \\
TOTAL OF STUDIES INCLUDED: 2 \\
\hline
\end{tabular}

LILACS: 1 article found

$1^{\text {st }}$ reading: titles and abstracts of articles

- The article did not approach the thematic

\section{SUBTOTAL OF STUDIES INCLUDED: 1}

$2^{\text {nd }}$ and $3^{\text {rd }}$ reading: full-text articles

- The article did not approach the thematic

TOTAL OF STUDIES INCLUDED: 0
CINAHL: 8 articles found

$1^{\text {st }}$ reading: titles and abstracts of articles

- 2 did not approach the thematic

- 3 were not available electronically

SUBTOTAL OF STUDIES INCLUDED: 3

$2^{\text {nd }}$ and $3^{\text {rd }}$ reading: full-text articles

- 2 do not respond to research questions

TOTAL OF STUDIES INCLUDED: 1

SCIENCE DIRECT: 36 articles found

$1^{\text {st }}$ reading: titles and abstracts of articles

- 27 did not approach the thematic

- 3 were not available electronically

SUBTOTAL OF STUDIES INCLUDED: 6

$2^{\text {nd }}$ and $3^{\text {rd }}$ reading: full-text articles

- 1 does not respond to research questions

- 1 was repeated in other databasis

TOTAL OF STUDIES INCLUDED: 4

Figure 1 - Selection process of articles carried out from August to October 2015

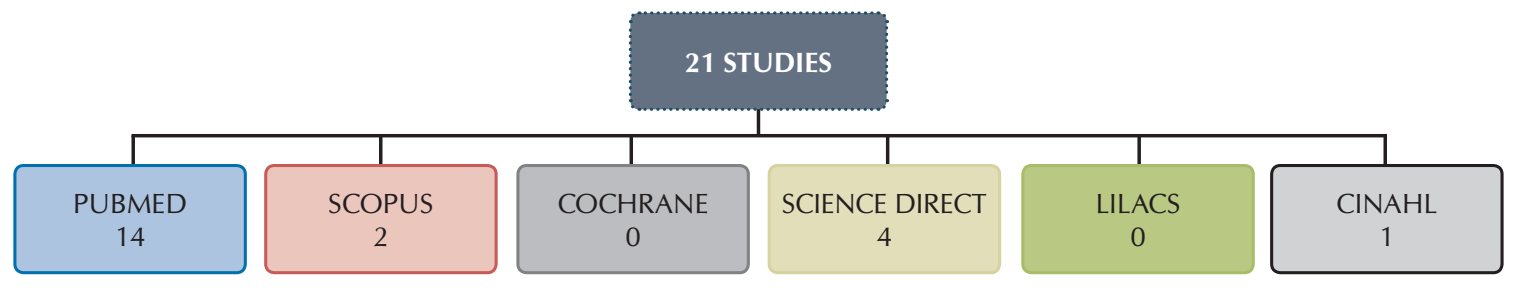

Figure 2 - Total selected studies for Concept Analysis 


\section{Method of Concept Analysis by Walker and Avant}

The steps for the operationalization of the concept analysis of Walker and Avant ${ }^{(4)}$ are: 1. Choice of concept; 2. Determination of the purpose of the analysis; 3. Identification of the uses of the concept; 4 . Determination of critical attributes or definers; 5. Identification of model cases; 6 . Identification of additional cases; 7 . Identification of antecedents and consequent; and 8. Determination of empirical references.

To support the investigation of the critical or defining attributes that discuss Impaired Verbal Communication in patients with ALS, the following questions were used: How do the authors define the concept? What are the characteristics or attributes? What ideas do the authors discuss about Impaired Verbal Communication in patients with ALS?

The antecedent and consequent events were identified, respectively, through the following questions: What events, situations and or phenomena contribute to the evidence of Impaired Verbal Communication in individuals with ALS? What are the clinical events, situations, or outcomes resulting from Impaired Verbal Communication in individuals with ALS?

The answers to these questions were found from the search of these in the selected articles. Afterwards, a correlation was made between antecedents found in the literature with Risk Factors and consequent ones with the defining characteristics of the nursing diagnosis of Impaired Verbal Communication. Thus, the possibility of including new Risk Factors and defining characteristics not mentioned in NANDA-I, but considered relevant by the literature.

Next, a characterization of the selected articles is presented and then the results are presented according to the steps of the concept analysis adopted, except for the description of the empirical references, since it is not necessary to contemplate the proposed objective.

\section{RESULTS}

The articles originated mainly from the United States, with $57.1 \%$, followed by the United Kingdom, with $14.3 \%$. No study published in Brazil was found in the databases studied. The majority were published between 2011 and 2015, corresponding to 42.9\% of the studies, whereas only two articles were published before the year 2000. Regarding the subjects' age group, the studies mainly involved a mixed population of adults and elderly in the same sample, with prevalence of $47.6 \%$. As the main scenario, there was a prevalence of secondary care with $38.1 \%$, including studies performed in specialized outpatient services and care in neurological clinics.

Regarding the topics addressed, the studies focused on speech therapy and the use of alternative communication, with a prevalence of $52.4 \%$, followed by the discourse deficit (19\%) and the communication strategies used by these patients $(9.5 \%)$. The researches were carried out in the same proportion by medical professionals and by the multiprofessional team, with $33.3 \%$. Also noteworthy is the lack of publications in the area of Nursing.

Regarding the study design, we highlight the cohort or case-control studies, well delineated $(47.6 \%)$ related to level IV evidence, followed by a review of descriptive or qualitative studies $(28.6 \%)$, level of evidence $\mathrm{V}$, and descriptive or qualitative studies (14.3\%), level of evidence VI.

\section{Analysis of the concept "Communication Disorders"}

\section{Concept selection and determination of the objective of concept analysis}

The concept chosen for the analysis was "Communication Disorders", being evidenced from the search in the DeCs as a descriptor related to the nursing diagnosis under study, Impaired Verbal Communication. The objectives were: To review the nursing diagnosis content of Impaired Verbal Communication in patients with ALS to identify their uses, critical attributes, possible antecedents and consequent.

\section{Identification of the uses of the concept}

Among the studies analyzed ${ }^{(7-15)}$, it was evidenced that they use the concept "Communication Disorders" to represent disorders present in speech, demonstrated by speech and speech disorders in ALS patients. However, the study by Roberts-South et al. ${ }^{(16)}$, besides the speech alteration, also addresses change in writing fluency. Ferguson and Boller ${ }^{(17)}$, in turn, treat this concept as a disorganization of written language, evidenced by syntax and spelling errors in this same population.

\section{Critical or essential attributes of the concept "Communica- tion Disorders"}

In the Chart below, it is present the expressions found in the literature for the term "Communication Disorders".

Chart 1 - Critical attributes evidenced in the literature of the term "Communication Disorders" in people with Amyotrophic Lateral Sclerosis, Brazil, 2016

\begin{tabular}{|l|}
\hline \multicolumn{1}{|c|}{ CRITICAL ATTRIBUTES OF “COMMUNICATION DISORDERS" } \\
\hline Comunicação voluntária diminuída; fala prejudicada ${ }^{(7)}$. \\
\hline Produção da fala torna-se incompreensível até para o ouvinte mais familiar nas interações ricas em informação contextual; falhas na comunicação ${ }^{(8)}$. \\
\hline Déficit na comunicação; alterações na fala; lentos na fluência da fala e escrita; alteração na fluência da escrita ${ }^{(16)}$. \\
\hline $\begin{array}{l}\text { Deterioração da fala; falta de habilidades de fala para satisfazer as necessidades diárias; Diminuição da compreensão das modalidades } \\
\text { verbais: escrita e fala }{ }^{(18)} \text {. }\end{array}$ \\
\hline $\begin{array}{l}\text { Problemas de comunicação oral devido à fraqueza, incoordenação, ou paralisia da musculatura da fala; alterações na fala; dificuldades } \\
\text { de comunicação; perda de comunicação }{ }^{(9)} \text {. }\end{array}$ \\
\hline $\begin{array}{l}\text { Déficit no discurso narrativo; padrão de discurso narrativo prejudicada; problemas na fala; desempenho da linguagem prejudicada; } \\
\text { dificuldade de execução da fala }{ }^{(10)} \text {. }\end{array}$ \\
\hline
\end{tabular}




\section{CRITICAL ATTRIBUTES OF “COMMUNICATION DISORDERS"}

Perda da comunicação falada; diminuição da capacidade de utilizar a voz; perda da capacidade de atender às necessidades diárias de comunicação com seu discurso natural; incapacidade de falar por longos períodos de tempo antes da morte; rápida perda da fala; perda rápida de expressão; perda do discurso ${ }^{(11)}$.

Perda da comunicação; perda da utilização da fala; Alteração da linguagem falada e escrita(19).

Perda da fala; deterioração gradual da capacidade da fala; perturbações da fala; dificuldades de comunicação; problema em transmitir e/ ou compreender a mensagem; dificuldades com a fala ${ }^{(12)}$.

Distúrbios de comunicação; deterioração da fala; dificuldades funcionais de comunicação por serem incapazes de satisfazer todas as suas necessidades de comunicação através do discurso oral; perda de expressão verbal; problemas de fala; perda da capacidade de usar o discurso natural; deterioração do discurso; impossibilidade de fala ${ }^{(13)}$.

Fala e linguagem prejudicada; conversa prejudicada; deficiências de comunicação; deficiências na fala ${ }^{(14)}$.

Disfunção da fala; problemas de fala; incapacidade para se comunicar ${ }^{(15)}$.

Comprometimento progressivo da linguagem escrita; comprometimento da fala; escrita desordenada; escrita anormal(17).

Perda da capacidade para falar e escrever; perda progressiva da capacidade de se comunicar com discurso natural; perda de discurso inteligível; perda do discurso natural; perda do discurso funcional; perda do discurso ${ }^{(20)}$.

When analyzing the concept of "Communication Disorders" as evidenced in the literature, the following critical attributes were identified as key elements: difficulties in speech ${ }^{(10,12-13)}$, slow fluency of speech ${ }^{(16)}$, decreased ability to use voice ${ }^{(11,13,19)}$, inability to speak for long periods ${ }^{(11)}$, decreased voluntary communication ${ }^{(7)}$, inability to communicate ${ }^{(11-12,15,19-20)}$, slow writing fluency $^{(16)}$, and messy writing ${ }^{(17)}$.

\section{Construction of a model case}

J. A. L., 50 years old, male, married, born in Pernambuco and coming from Fortaleza-CE. Five years ago he started a picture of painful and frequent cramps, associated with muscle weakness in the left lower limb that progressed with atrophy of the left hand, being diagnosed six months later with ALS. He was followed up by a neurologist, a nurse and a physiotherapist regularly at home. Ten months after the onset of symptoms, the patient reports that he began to present difficulties when communicating, being reported by the health team the presence of a slow fluency of speech, decreased ability to use voice and inability to speak for long periods due to fatigue. The family reports that the patient presented a decrease in voluntary communication. The early onset of dyspnea on the small exertions, which at first was only noticed when playing soccer, required the use of tracheostomy, with a consequent inability to communicate through speech. The communication with his family and friends occurred through computer writing, which for some months has been drastically impaired by the rapidly progressive evolution of the loss of hand and finger movements, resulting in a slow flow of writing added to a disordered writing.

The presence of some essential attributes found in the literature, such as speech difficulties, slow fluency of speech, decreased ability to use the voice, inability to speak for long periods, a decrease in voluntary communication, a disability to communicate, slow writing fluency and disordered writing, thus characterizing JAL with an Impaired Verbal Communication.

\section{Construction of an opposite case}

J. F. G., 68 years old, male, retired, married, natural and from Fortaleza-Ceará State. Thirteen years ago, he started a picture of lower limb muscle weakness and was diagnosed with ALS eight months after the onset of symptoms. With the progression of the disease, he felt strong muscular spasms and cramps in lower limbs, but without the presence of dyspnea to the efforts. Four years after the onset of symptoms, he was unable to walk due to total paralysis of the lower limbs, using a wheelchair for locomotion. Despite the progression of symptoms in lower limbs, verbal communication remains unchanged by the preservation of speech, voice and written language. The latter, caused by the preservation of strength in upper limbs and organized writing, without syntax and spelling errors. During the outpatient visit, he reports that he is distressed because he is unable to perform his favorite activities, such as driving and riding, but is happy to communicate normally without difficulty in understanding and/or transmitting messages with his relatives and friends, despite the progression of the disease.

In this case, it is explicit that J.F. G. does not present Impaired Verbal Communication, since it did not contemplate the critical attributes necessary for the patient to be considered with Communication Disorders.

Thus, based on the appreciation of the essential critical attributes of "Communication Disorders" evidenced in the literature, a single, objective and clarified definition that considers the results of this conceptual analysis:

It refers to impairment in the production of speech, voice or writing, due to the difficulty in transmitting and/or understanding a message.

It refers to impairment in the production of speech, voice or writing, due to the difficulty in transmitting and/or understanding a message.

\section{Identification of antecedents}

Table 1 shows the sixteen Risk Factors and evidenced in the nursing diagnosis literature of Impaired Verbal Communication. 
Table 1 - Risk Factors evidenced in the literature, Brazil, 2016

\begin{tabular}{|c|c|}
\hline RF - Concept analysis & RF - Concept analysis \\
\hline Degeneration of motor neurons $s^{(7-8,13,15,18)}$ & Vocal fold hyperadduction ${ }^{(7,19)}$ \\
\hline Tongue paralysis ${ }^{(7-8,15,18-20)}$ & Vocal fold hypoadduction ${ }^{(7,19)}$ \\
\hline Reduced tongue speed ${ }^{(7-8,15,18-20)}$ & Respiratory muscle weakness ${ }^{(8,19)}$ \\
\hline Tongue atrophy $(7,19)$ & Dyspnea $^{(7,17)}$ \\
\hline Tongue fasciculations $(7,17,20)$ & Tracheostomy $^{(19)}$ \\
\hline Hemifacial spasm ${ }^{(7,19)}$ & Sialorrhea ${ }^{(7,20)}$ \\
\hline Flaccid facial paralysis ${ }^{(7,19)}$ & Emotional lability ${ }^{(12,20)}$ \\
\hline Velopharyngeal insufficiency ${ }^{(7-8,15,19-20)}$ & Cognitive deficits ${ }^{(12-13,16,20)}$ \\
\hline
\end{tabular}

Note: $R F=$ Risk Factors

\section{Identification of consequent}

Table 2 shows the twelve defining characteristics and evidenced in the nursing diagnosis literature of Impaired Verbal Communication.

Table 2 - Defining characteristics evidenced in the literature, Brazil, 2016

\begin{tabular}{|c|c|}
\hline DC - Concept analysis & DC - Concept analysis \\
\hline Dysgraphia $^{(16-17,19)}$ & Intelligibility of impaired speech ${ }^{(7,9,11-13,15,19-20)}$ \\
\hline Agraphia $^{(17,20)}$ & Decline of speech rate $(11,13,15,20)$ \\
\hline Dysarthria ${ }^{(7-9,12-16,18-20)}$ & Reduction of speech productivity $(10,13-14,16)$ \\
\hline Anartria $(7,9,19)$ & Decrease of ability and/or willingness to social interaction ${ }^{(8,11-13)}$ \\
\hline Aphasia ${ }^{(8,16-17,19)}$ & Augmentative and alternative communication ${ }^{(9,11-13,18-20)}$ \\
\hline Fatigue from conversation ${ }^{(9,11-12,16,19)}$ & Negative emotions ${ }^{(9,11-13,20)}$ \\
\hline
\end{tabular}

Note: $D C=$ Defining characteristics

\section{DISCUSSION}

\section{Characterization of the studies}

The results showed that the studies are primarily publications from countries in North America and Europe, and almost all from the 2000s, thus corroborating with Santos' finding ${ }^{(21)}$ on the study of the diagnosis in question. However, none addressed communication as a nursing diagnosis. The authors were mainly from the medical and multiprofessional area and because it is a condition that affects multiple systems, it is natural that their approach is largely multidisciplinary. However, it is necessary for nurses to take on their role in patient care and to take.

The studies were developed mainly in secondary care, with adult and elderly participants, thus depicting the age range of the disease. And they emphasized mainly the theme of speech therapy and the use of alternative communication, evidencing the interest of the authors in the rehabilitation of the patient. Regarding the level of evidence, there was a predominance of studies with level of evidence IV, which are cohort or case-control studies. Publications that depict strong clinical evidence are still punctual, such as systematic reviews/meta-analysis. However, the deficiency of studies with a high level of evidence does not prevent knowledge-based decision making and scientific support, since nurses should seek the best evidence available and not the best possible evidence ${ }^{(22)}$.

\section{Concept analysis}

In the face of the concept analysis, critical attributes were extracted that fomented the elaboration of a new definition for the nursing diagnosis of Impaired Verbal Communication: impairment in the production of speech, voice or writing due to the difficulty in transmitting and/or understanding a message.

Communication is defined as a medium used for the exchange of information, understanding of meanings, and relationship between individuals and the environment in which they are inserted. During communication, the transmission, reception and comprehension of messages that can be verbal through spoken or written language, and non-verbal messages, are expressed through gestures and symbols ${ }^{(23)}$. Symbol is defined as a figure or image that represents in sight what is purely abstract; signal; figure by which one substitutes or suggests something by a signal that the use adopted to designate it ${ }^{(24)}$.

Monteiro $^{(25)}$ defines non-verbal communication as the different means of communication between living beings who do not use written or spoken language or their nonsound derivatives, such as the language of the deaf-mute. Ramos and Bortagarai $^{(26)}$ and Galvão ${ }^{(27)}$ exemplify nonverbal communication as: facial expression; look; gestures and body movements; body posture; spatial behavior; the use of space by communicators; vocal or paralinguistic signs; touch language or body contact; objects and adornments used; physical characteristics; the moment when words are spoken; and environmental factors.

Speech, voice and writing, however, are reported as necessary means for verbal communication to occur. According to Vitto and Feres ${ }^{(28)}$, the voice refers to the simple sound emission produced by the larynx, corresponding to the sound with which words and singing are emitted. Speech refers to the articulation of the voice, producing words, being described as the sound translation of language. Writing, in turn, refers to the representation of spoken language by means of signs or graphic symbols.

NANDA- $I^{(1)}$, however, defines Impaired Verbal Communication as diminished, delayed, or absent ability to receive, process, transmit and/or use a symbol system. According to what has been stated, NANDA-I goes beyond the definition of verbal communication when it reports on the use of symbol system, since the meaning of the word symbol is comprehensive and may include aspects of verbal and non-verbal communication. As a result, a new concept based on the concept analysis was proposed for the nursing diagnosis under study, where it is possible to note a greater adequacy between the title and its definition.

Regarding the Risk Factors, the "degeneration of motor neurons" was found. Kühnlein et al. ${ }^{(7)}$ state that both the degeneration of motor superior neurons and the degeneration of lower motor neurons, located in the bulb and in the spinal cord, cause changes in oral communication.

NANDA-I adduces the Risk Factor "impairment in the central nervous system". However, it is known that the degeneration of 
motor neurons is only one of the damage that can occur in the central nervous system. This specificity is due to the fact that the study was developed in a specific population.

"Flaccid facial paralysis" and "hemifacial spasm" are Risk Factors reported by Tomik and Guiloff ${ }^{(19)}$, resulting in a difficult and slurred speech that compromises communication. Another found risk factor was tongue paralysis and reduced tongue speed, which is described by Hanson, Yorkston and Britton ${ }^{(20)}$ as physiological factors that result in decreased speech intelligibility.

Kühnlein et al. ${ }^{(7)}$ reported that hyperadduction and hypoadduction of the vocal chords can be verified in ALS patients, causing an altered voice pattern, thus giving subsidy to the Risk Factors to "vocal fold hyperadduction" and "vocal fold hypoadduction". Ball, Beukelman and Pattee ${ }^{(8)}$ report that respiratory muscle weakness results in inappropriate vocal sonority and the difficulty of producing long sentences by the need for frequent breaths.

Risk Factors such as hemifacial spasm, flaccid facial paralysis, tongue paralysis, reduced tongue speed, vocal fold hyperadduction, vocal fold hypoadduction, and respiratory muscle weakness could be allocated within the existing Risk Factor "physiological conditions" NANDA-I, due to the examples cited in NANDA-I itself. However, it was considered incongruous to aggregate them to the existing Risk Factor because they considered that the identified Risk Factors are not a physiological condition, but a change of this. Reinforcing the idea presented here, Guyton and Hall ${ }^{(29)}$ report that physiology studies the organic functions under normal conditions.

Regarding the Risk Factor "velopharyngeal insufficiency", it cannot be said that it corresponds to the Risk Factor "oropharyngeal defect" described in NANDA-I, because besides the oropharyngeal cavity it has other structures besides those involving velopharyngeal insufficiency, word "defect", as a medical term in the Priberam Dictionary ${ }^{(30)}$, means deformity or imperfection in the form of an organ or a part of the body, and the word "insufficiency" means lack of competence, inability, and inability. Thus, a new Risk Factor is suggested, since "insufficiency" refers to the function of the organ and "defect" refers to the anatomy.

"Tongue atrophy", according to the study by Kühnlein et al. ${ }^{(7)}$, favors the appearance of communication difficulties, since it is considered the main articulator of speech. In turn, Hanson, Yorkston, Britton $^{(20)}$ report that tongue fasciculations are among the symptoms responsible for the perceptible change in discourse. Thus, they have as Risk Factor: "tongue atrophy" and "tongue fasciculations". These two Risk Factors do not have any analogues in NANDA-I, thus portraying new Risk Factors revealed in the concept analysis.

Regarding the Risk Factor "dyspnea", Green et al.(31) report that patients with ALS inevitably have dyspnea, due to progressive respiratory dysfunction, causing irregular breaths and, consequently, frequent pauses during speech, thus evidencing a causal relationship between dyspnea and oral communication, and not an effect relationship, as portrayed in NANDA-I.

Tomik and Guiloff(19) refer to tracheostomy as a physical barrier that impairs oral communication. Silva ${ }^{(32)}$ explains that tracheostomy impairs oral communication due to the sealing in the trachea, causing the air to pass only inside the cannula and, consequently, preventing the production of speech sounds. However, for speech to occur, the passage of air through the vocal cords is necessary. Thus, patients with ALS, when they are in a slightly more advanced stages of the disease, need this respiratory support, concluding that "tracheostomy" is a Risk Factor for Communication Disorders.

In addition, NANDA-I also presents the Risk Factor "physical barrier (e.g., tracheostomy)", expressing analogy with what was found in the literature, however, it exemplifies the physical barrier, citing not only tracheostomy but also orotracheal intubation.

In patients with ALS, sialorrhea is present due to the difficulty in swallowing saliva, associated with the difficulty of keeping the lips sealed to keep the saliva in the mouth, impairing communication $^{(7,20)}$. NANDA-I does not show any correlative Risk Factor.

Emotional lability is revealed by Hanson, Yorkston and Britton $^{(20)}$ as a frequent problem in patients with ALS, being reported as causing embarrassment and significant impact on communication, especially during communication with unknown people, because they are not aware of the problem.

The Risk Factor "emotional lability" has its correspondent in the NANDA-I called Emotional Disturbance. It is assumed that other emotional disturbances can be revealed from the concept analysis in other specific populations.

Regarding the Risk Factor "cognitive deficits", Roberts-South et al. ${ }^{(16)}$ report that a subset of patients with ALS have cognitive impairment that negatively affects communication and these include disturbances in systems and processes of attention to executive functions, multiple memory systems and visuospatial abilities, work memory, cognitive flexibility and sustained attention, as well as memory of words and faces recognition, visual perception, reasoning and executive functions such as planning, organization and self-monitoring. The Risk Factor "cognitive deficits", however, does not have any correlates in NANDA-I, thus portraying a new Risk Factor revealed in the concept analysis.

As for defining characteristic, "dysgraphia", characterized as a difficulty in writing, is evidenced by Roberts-South et al. ${ }^{(16)}$ that ALS patients with speech disorders present with letter deficits, semantics and writing fluency. Corroborating with the above ideas, Severo ${ }^{(33)}$ reveals that communication through writing is hampered by the atrophy of the muscles of the hands, due to decreased movement and motor coordination. Thus, we have a new defining characteristic revealed in the study.

With regard to "agraphia", characterized by the impossibility of communicating through writing, Hanson, Yorkston and Britton ${ }^{(20)}$ reported that the majority of people diagnosed with ALS lose their ability to write due to the worsening of the motor deficits of the limbs. Thus "agraphia" presents itself as a new defining characteristic.

"Dysarthria" was the most expressive symptom for Impaired Verbal Communication in the literature. Ray13 reports that dysarthria is responsible for severe functional communication difficulties in ALS patients due to their inability to meet their communication needs using oral speech. This symptom occurs due to motor impairment of speech within any or all of the speech subsystems, including difficulties with breathing, phonation, resonance, articulation, and prosody ${ }^{(12,14)}$.

One of the characteristics of dysarthria includes difficulty with the enunciation or pronunciation of words, preventing the production of precise speech. It presents itself as a weakened voice and a difficult, slow, slurred $\operatorname{speech}^{(7,20)}$. 
Another defining characteristic reported was "anartria", which presents as a total inability to speak, due to a difficulty in articulating the words, resulting from a well advanced state of dysarthria ${ }^{(7)}$.

In the face of the characterization of dysarthria and anarthria above and correlating with defining characteristics present in NANDA-I: difficulty in forming words, slurred speech, difficult speech and difficult verbalization are found in people with dysarthria and the defining characteristic cannot speak is found in people with anarthria.

Although these mentioned characteristics are present in dysarthritic and anarthritic patients, it is recommended not to group them because they know that more studies must be performed in order to verify the occurrence of them in patients with diseases other than dysarthria or anarthria.

"Aphasia", also reported as a symptom in the studies analyzed, is characterized by the loss of one or all areas of language, such as: listening comprehension, reading comprehension, writing production and production of spoken language, resulting in compromised communication ${ }^{(14)}$.

According to the characterization of the different types of aphasia, the defining characteristics present in NANDA-I: difficulty in forming sentences, difficulty in understanding communication, difficulty in verbally expressing thoughts and inadequate verbalization, are present in people with aphasia. However, the defining characteristics "difficulty in understanding" and "difficulty in verbally expressing thoughts" are the primary characteristics of aphasia, in view of the very concept of aphasia, being correspondents.

Although the other defining characteristics mentioned in the paragraph above are also present in aphasic patients, it is recommended not to correlate them with aphasia because they know that other affections such as disorientation due to infectious causes or metabolic alterations can also present symptomatologies, such as "difficulty in forming sentences" and "inadequate verbalization", being therefore reason for other specific studies.

Concerning the defining characteristic "fatigue from conversation", Brownlee and Palovcak ${ }^{(9)}$ report that fatigue appears during the moment of conversation due to the effort required to use the muscles involved in speech that are already damaged making communication even more difficult. Mckelvey et al. ${ }^{(11)}$ report on fatigue from conversation through writing, which also requires increased effort to communicate.

The characteristic "intelligibility of impaired speech" was a symptom referred to by Brownlee and Palovcak ${ }^{(9)}$ as a decrease or lack of understanding of the listener in relation to the acoustic signal produced by the ALS patient.

Rong et al. ${ }^{(34)}$ report that the deceleration of the speech rate to 120 words per minute marks the beginning of rapid and substantial declines in discourse and may vary according to the affected speech subsystem.

The reduction of speech productivity is described by Ash et al. ${ }^{(10)}$ as a reduction in the number of complete words spoken, number of statements made and accuracy of the content that occurs as a compensatory mechanism because of fatigue, speech motor deficiency or of impaired control of breathing, thus presenting as a consequence of Impaired Verbal Communication.
In relation to the described characteristics described as "fatigue from conversation", "intelligibility of impaired speech", "decline of speech rate" and "reduction of speech productivity", in turn, do not present any analogue in NANDA-I, thus portraying new characteristics revealed in the concept analysis carried out.

The defining characteristic "decrease of ability and/or willingness to social interaction" was thus named from the report by Mckelvey et al. ${ }^{(11)}$ on the decrease in ALS patients of the ability to maintain social closeness with family and friends due to the difficulty in communication, as well as through Murphy's report $^{(12)}$ about the decrease in the disposition and refusal of individuals with ALS to become involved in social interactions due to fatigue during the dialogue.

NANDA-I presents a defining characteristic called "refusal to speak", which is analogous to that found in the concept of "decrease of ability and/or willingness to social interaction".

"Augmentative and alternative communication" is reported by Cohen et al. ${ }^{(35)}$ as necessary when deterioration of the ability to communicate occurs. Hanson, Yorkston, and Britton ${ }^{(20)}$ define this defining characteristic, "augmentative and alternative communication", as any type of communication other than the patient's natural speech or writing.

"Negative emotions" are also a consequence of a communication deficit, which further hampers the occurrence of effective communication. Significant evidence of emotions, such as frustration, fear, depression, anxiety, sadness, mood deterioration, anger and feelings of hopelessness are discussed in the studies analyzed $(9,13,20,36)$.

NANDA-I, however, does not present any defining characteristic congener to "augmentative and alternative communication" and "negative emotions", in this way, portraying two new defining characteristics unveiled in the concept analysis.

Cavalcante et al. ${ }^{(37)}$ emphasize that the validation of nursing diagnoses in specific populations is recommended. In view of this, because the content review was performed on patients with ALS, we found differences in the concept analysis performed in relation to the nursing diagnosis published in NANDA-I. It was verified that this nursing diagnosis was formulated based on different contexts, justifying the non-correspondence of 14 Risk Factors and 21 defining characteristics present in the NANDA-I with antecedents and consequent found in the analyzed literature.

\section{Study limitations}

Due to the need to choose languages to search for articles, other important studies in languages other than those selected may present relevant defining characteristics and risk factors, but were not accessed.

\section{Contributions to the sectors of Nursing, Health or Public Policy}

The study allowed a clarification of the chosen concept, allowing later studies to work to refine and improve this diagnosis and its components. In teaching, it will enable a better understanding of the concepts involved, facilitating the student's approach and learning in the subject in question. Thus, nursing knowledge is elevated to a higher level of support, with great contributions to the NANDA-I reviewers, thus ensuring a greater trustworthiness of the diagnoses, bringing theory closer to practice. 


\section{CONCLUSION}

The content review process aimed at the objective of the study subsidized the proposed reformulation of the nursing diagnosis of Impaired Verbal Communication.

It is therefore recommended to maintain the title suggested by NANDA-I: "Impaired Verbal Communication" and proposed a new definition: it refers to impairment in the production of speech, voice or writing due to the difficulty in transmitting and/or understand a message.

It is recommended to reallocate a defining characteristic for Risk Factor, the incorporation of twelve Risk Factors and the maintenance of three others. Thus, the final proposal is sixteen Risk Factors, namely: "degeneration of motor neurons"; "tracheostomy"; "emotional lability"; "dyspnea"; "hemifacial spasm"; "flaccid facial paralysis"; "tongue paralysis"; "reduced tongue speed"; "vocal fold hyperadduction"; "vocal fold hypoadduction"; "respiratory muscle weakness"; "velopharyngeal insufficiency"; "tongue atrophy"; "tongue fasciculations"; "sialorrhea"; "cognitive deficits". It should be noted that the first three Risk Factors already make up the taxonomy. The fourth Risk Factor is positioned in NANDA-I within the defining characteristics and the remainder is new Risk Factors.
Relevant to the defining characteristics, the addition of nine more characteristics and the modification of the nomenclature of other three are recommended. The final proposal is of twelve defining characteristics, namely: "dysarthria"; "decrease of ability and/or willingness to social interaction"; "aphasia"; "anartria"; "dysgraphia"; "agraphia"; "fatigue from conversation"; "intelligibility of impaired speech"; "decline of speech rate"; "reduction of speech productivity"; "augmentative and alternative communication"; "negative emotions". The first three defining characteristics already compose the taxonomy, proposing the modification of their nominations, passing the defining characteristic "difficulty in forming words" to the denomination "dysarthria", from "refusal to speak" to "decrease of ability and/or willingness to social interaction" and "difficulty in verbally expressing thoughts" to "aphasia". The other ones are new defining characteristics.

In view of the above, it is suggested to carry out new studies in this subject, with the purpose of deepening and diffusing the knowledge about this diagnosis in different contexts. It is also essential to perform the validation by specialists and clinical validation to confirm the results found involving patients with ALS.

\section{REFERENCES}

1. NANDA-I. Diagnósticos de enfermagem da NANDA: definições e classificação 2015-2017. 10th ed. Porto Alegre: Artmed; 2015.

2. Guedes NG. Revisão do diagnóstico de enfermagem estilo de vida sedentário: análise de conceito e validação por especialistas[Tese]. Fortaleza: Faculdade de Farmácia, Odontologia e Enfermagem, Universidade Federal do Ceará; 2011.

3. Lopes MVO, Silva VM, Araujo TL. Methods for establishing the accuracy of clinical indicators in predicting nursing diagnoses. Int J Nurs Knowl[Internet]. 2012[cited 2015 Feb 19];23(3):134-9. Available from: https://doi.org/10.1111/j.2047-3095.2012.01213.x

4. Walker LO, Avant KC. Strategies for theory construction in nursing. 5th ed. Upper Saddle River: Pearson Prentice Hall; 2011.

5. Whittemore R, Knafl K. The integrative review: updated methodology. J Adv Nurs[Internet]. 2005[cited 2015 Mar 10];52(5):546-53. Available from: https://doi.org/10.1111/j.1365-2648.2005.03621.x

6. Melnyk BM, Fineout-Overholt E. Evidence-based practice in nursing \& healthcare: a guide to best practice. Philadelphia: Lippincott Williams \& Wilkins; 2010.

7. Kühnlein P, Gdynia H-J, Sperfeld A-D, Lindner-Pfleghar B, Ludolph AC, Prosiegel M, Riecker A. Diagnosis and treatment of bulbar symptoms in amyotrophic lateral sclerosis. Nat Clin Pract Neurol[Internet]. 2008[cited 2015 Dec 02];4(7):366-74. Available from: https://www.rku.de/files/Diagnosis_and_treatment_of_bulbar_symptoms_in_amyotrophic_lateral_sclerosis_Khnlein_et_al_2009.pdf

8. Ball LJ, Beukelman DR, Pattee GL. Communication effectiveness of individuals with amyotrophic lateral sclerosis. J Commun Disord[Internet]. 2004[cited 2015 Dec 18];37(3):197-215. Available from: https://linkinghub.elsevier.com/retrieve/pii/ S0021992403000789

9. Brownlee A, Palovcak M. The role of augmentative communication devices in the medical management of ALS. NeuroRehabilitation[Internet]. 2007[cited 2016 Jan 03];22(6):445-450. Available from: https://www.ncbi.nlm.nih.gov/pubmed/18198430

10. Ash S, Menaged A, Olm C, Mcmillan CT, Boller A, Irwin DJ, et al. Narrative discourse deficits in amyotrophic lateral sclerosis. Neurol[Internet]. 2014[cited 2016 Jan 17];83(6):520-28. Available from: https://www.ncbi.nlm.nih.gov/pmc/articles/PMC4142005/

11. Mckelvey M, Evans DL, Kawai N, Beukelman D. Communication styles of persons with ALS as recounted by surviving partners. Augment Altern Commun[Internet]. 2012[cited 2016 Jan 22];28(4):232-42. Available from:https://www.ncbi.nlm.nih.gov/ pubmed/23256855

12. Murphy J. Communication strategies of people with ALS and their partners. Amyotroph Lateral Scler Other Motor Neuron Disord[Internet]. 2004[cited 2016 Feb 28];5(2):121-6. Available from: https://www.ncbi.nlm.nih.gov/pubmed/15204014

13. Ray J. Real-life challenges in using augmentative and alternative communication by persons with amyotrophic lateral sclerosis. Commun Disord Q[Internet]. 2015[cited 2016 Mar 12];36(3):187-92. Available from: http://journals.sagepub.com/doi/ abs/10.1177/1525740114545359 
14. Bloch S, Beeke S. Co-constructed talk in the conversations of people with dysarthria and aphasia. Clin Linguist Phon[Internet]. 2008[cited 2016 Mar 21];22(12):974-90. Available from: https://www.ncbi.nlm.nih.gov/pubmed/19031194

15. Ball LJ, Willis A, Beukelman DR, Pattee GL. A protocol for identification of early bulbar signs in amyotrophic lateral sclerosis. J Neurol Sci[Internet]. 2001[cited 2016 Apr 04];191(1-2):43-53. Available from: https://linkinghub.elsevier.com/retrieve/pii/ S0022510X01006232

16. Roberts-South A, Findlater K, Strong MJ, Orange JB. Longitudinal changes in discourse production in amyotrophic lateral sclerosis. Semin Speech Lang[Internet]. 2012[cited 2015 Nov 15];33(1):79-94. Available from: http://www.thieme-connect.com/DOI/ DOI?10.1055/s-0031-1301165

17. Ferguson JH, Boller F. A different form of "pure agraphia": syntactic writing errors in patients with motor speech and movement disorders. Neurol Neurocir Psiquiatr[Internet]. 1977[cited 2015 Nov 22];4(3):382-89. Available from: https://www.ncbi.nlm.nih. gov/pubmed/616562

18. Bloch S, Clarke M. Handwriting-in-interaction between people with ALS/MND and their conversation partners. Augment Altern Commun[Internet]. 2013[cited 2015 Dec 23];29(1):54-67. Available from: http://www.tandfonline.com/doi/full/10.3109/07434 618.2013.767497

19. Tomik B, Guiloff RJ. Dysarthria in amyotrophic lateral sclerosis: a review. Amyotroph Lateral Scler[Internet]. 2010 [cited 2016 Feb 12];11(1-2):4-15. Available from: http://www.tandfonline.com/doi/full/10.3109/17482960802379004

20. Hanson EK, Yorkston KM, Britton D. Dysarthria in amyotrophic lateral sclerosis: a systematic review of characteristics, speech treatment, and augmentative and alternative communication options. J Med Speech Lang Pathol[Internet]. 2011 [cited 2016 Apr 13];19(3):12-30. Available from: https://www.asha.org/articlesummary.aspx?id=8589955557

21. Santos NA. Revisão teórica do diagnóstico de enfermagem comunicação verbal prejudicada[Dissertação]. Fortaleza: Faculdade de Farmácia, Odontologia e Enfermagem, Universidade Federal do Ceará; 2015.

22. Pompeo DA, Rossi LA, Galvão CM. Integrative literature review: the initial step in the validation process of nursing diagnoses. Acta Paul Enferm[Internet]. 2009[cited 2016 Apr 25];22(4):434-8. Available from: http://www.scielo.br/pdf/ape/v22n4/en_a14v22n4.pdf

23. Pachet A, Allan L, Erskine L. Assessment of fluctuating decision-making capacity in individuals with communication barriers: a case study. Top Stroke Rehabil[Internet]. 2012[cited 2016 Apr 30];19(1):75-85. Available from: https://www.ncbi.nlm.nih.gov/ pubmed/22306631

24. Dicionário Priberam da Língua Portuguesa[Internet]. Lisboa: Priberam Informática; 2013[cited 2016 May 11]. Símbolo. Available from: https://www.priberam.pt/DLPO/S\%C3\%ADmbolo

25. Monteiro ASF. Gestos e sinais na consulta de medicina dentária[Dissertação]. Almada: Instituto Superior de Ciências da Saúde Egas Moniz[Internet]; 2016[cited 2016 May 13]. Available from: https://comum.rcaap.pt/bitstream/10400.26/17435/1/Monteiro_ Ana_Sofia_Feij\%c3\%a3o.pdf

26. Ramos AP, Bortagarai FM. A comunicação não-verbal na área da saúde. Rev CEFAC[Internet]. 2012[cited 2016 May 20];14(1):16470. Available from: http://www.scielo.br/pdf/rcefac/v14n1/186_10.pdf

27. Galvão MIZ. Comunicação interpessoal em cuidados paliativos: um estudo à luz da teoria de Peplau[Dissertação][Internet]. Brasília: Faculdade de Enfermagem, Universidade de Brasília; 2016[cited 2016 May 27]. Available from: http://repositorio.unb.br/ bitstream/10482/21635/1/2016_Marialren\%c3\%adZapalowskiGalv\%c3\%a3o.pdf

28. Vitto MMP, Feres MCLC. Distúrbios da comunicação oral em crianças. Med[Internet]. 2005[cited 2016 May 29];38(3-4):229-34. Available from: http://revista.fmrp.usp.br/2005/vol38n3e4/_vti_cnf/1_disturbios_comunicacao.pdf

29. Guyton AC, Hall JE. Tratado de Fisiologia Médica. 13th ed. São Paulo: Elsevier; 2017.

30. Dicionário Priberam da Língua Portuguesa[Internet]. Lisboa: Priberam Informática; 2013[cited 2016 Jun 02]. Available from: https:// www.priberam.pt/dlpo/Default.aspx

31. Green JR, Yunusova Y, Kuruvilla MS, Wang J, Pattee GL, Synhorst L, et al. Bulbar and speech motor assessment in ALS: challenges and future directions. Amyotroph Lateral Scler and Frontotemporal Degener[Internet]. 2013[cited 2015 Dec 08];14(7-8):494-500. Available from: https://www.ncbi.nlm.nih.gov/pmc/articles/PMC3833808/

32. Silva TB. Traqueostomia em pacientes internados em Unidades de Terapia Intensiva de hospitais públicos do Distrito Federal: Prevalência, indicações, tempo para realização do procedimento e técnica[Dissertação][Internet]. Brasília: Faculdade de Ceilândia, Universidade de Brasília; 2014[cited 2016 Jun 06]. Available from: http://repositorio.unb.br/bitstream/10482/16156/1/2014_ ThiagoBarbosaSilva.pdf

33. Severo AH. Esclerose lateral amiotrófica: conhecimento da qualidade de vida de pessoas acometidas[Monografia]. Fortaleza: Faculdade de Farmácia, Odontologia e Enfermagem, Universidade Federal do Ceará; 2013.

34. Rong P, Yunusova Y, Wang J, Green JR. Predicting early bulbar decline in amyotrophic lateral sclerosis: a speech subsystem approach. Behav Neurol[Internet]. 2015[cited 2016 Jan 08];2015:183027. Available from: http://downloads.hindawi.com/journals/ bn/2015/183027.pdf

35. Cohen SM, Elackattu A, Noordzij JP, Walsh MJ, Langmore SE. Palliative treatment of dysphonia and dysarthria. Otolaryngol Clin North Am[Internet]. 2009[cited 2016 Feb 17];42(1):107-21. Available from: https://linkinghub.elsevier.com/retrieve/pii/ 


\section{S0030-6665(08)00154-0}

36. Körner S, Siniawski M, Kollewe K, Rath KJ, Krampfl K, Zapf A, et al. Speech therapy and communication device: impact on quality of life and mood in patients with amyotrophic lateral sclerosis. Amyotroph Lateral Scler Frontotemporal Degener[Internet]. 2013[cited 2016 Mar 17];14(1):20-5. Available from: http://www.tandfonline.com/doi/full/10.3109/17482968.2012.692382

37. Cavalcante JCB, Mendes LC, Lopes MVO, Lima LHO. Indicadores clínicos de padrão respiratório ineficaz em crianças com asma. Rev Rene[Internet]. 2010[cited 2016 Jun 11];11(1):66-75. Available from: http://www.revistarene.ufc.br/revista/index.php/revista/ article/viewFile/348/pdf 